\title{
Bats of Buraco das Araras natural reserve, Southwestern Brazil
}

\author{
Nicolay Leme da Cunha ${ }^{1,3}$, Erich Fischer ${ }^{1}$, \\ Luiz Felipe Alves da Cunha Carvalho ${ }^{1} \&$ Carolina Ferreira Santos ${ }^{2}$ \\ 'Laboratório de Ecologia, Departamento de Biologia, \\ Universidade Federal de Mato Grosso do Sul - UFMS, \\ CEP 79070-900, Campo Grande, Mato Grosso do Sul, Brazil \\ 2Programa de Pós-Graduação em Ecologia e Conservação, \\ Universidade Federal de Mato Grosso do Sul - UFMS, \\ CEP 79070-900 Campo Grande, Mato Grosso do Sul, Brazil \\ ${ }^{3}$ Corresponding author: Nicolay Leme da Cunha, e-mail: nicolaycunha@gmail.com
}

CUNHA, N.L., FISCHER, E., CARVALHO, L.F.A.C. \& SANTOS, C.F. Bats of Buraco das Araras natural reserve, Southwestern Brazil. Biota Neotrop., 9(4): http://www.biotaneotropica.org.br/v9n4/en/ abstract?inventory+bn02909042009.

\begin{abstract}
The doline Buraco das Araras is a peculiar environment and important destiny for ecotourism in the Serra da Bodoquena region, Mato Grosso do Sul, Brazil. Here we describe the bat fauna of the doline and surrounding areas, and report its use as dayroost by the bat Nyctinomops laticaudatus. Bats were mist-netted during two field expeditions, in November 2007 and January 2008. We captured 153 individuals of 10 species, mainly $N$. laticaudatus $(\mathrm{n}=90)$ and Artibeus planirostris $(\mathrm{n}=28)$. This is the first record of $N$. laticaudatus in the Serra da Bodoquena region; it was captured only in January when leaving the doline in dense flocks at dusk. Phyllostomus hastatus, Micronycteris sanborni, and Molossops temminckii are also new records for the Serra da Bodoquena region. Three individuals - A. planirostris, Carollia perspicillata and Glossophaga soricina-tagged in November were recaptured in January, indicating that these species are residents. The doline and bordering vegetation appear to be important sources of shelter and food for bat fauna maintenance.
\end{abstract}

Keywords: dayroost, Cerrado, diversity, doline, Nyctinomops laticaudatus.

CUNHA, N.L., FISCHER, E., CARVALHO, L.F.A.C. \& SANTOS, C.F. Morcegos da Reserva Natural Buraco das Araras, sudoeste do Brasil. Biota Neotrop.,9(4): http://www.biotaneotropica.org.br/v9n4/pt/ abstract?inventory+bn02909042009.

Resumo: A dolina Buraco das Araras é um ambiente peculiar e importante destino para o ecoturismo na região da Serra da Bodoquena, Mato Grosso do Sul, Brasil. Descrevemos aqui a fauna de morcegos da dolina e entorno, e reportamos sua utilização como abrigo diurno pelo morcego Nyctinomops laticaudatus. Os morcegos foram capturados em redes de neblina durante duas expedições, em novembro de 2007 e janeiro de 2008. Capturamos 153 indivíduos de 10 espécies, principalmente $N$. laticaudatus $(\mathrm{n}=90)$ e Artibeus planirostris $(\mathrm{n}=28)$. Este é o primeiro registro de $N$. laticaudatus na região da Serra da Bodoquena; a espécie foi capturada apenas em janeiro quando indivíduos deixavam a dolina em denso agrupamento ao anoitecer. Phyllostomus hastatus, Micronycteris sanborni e Molossops temminckii também são novos registros para a região da Serra da Bodoquena. Três indivíduos - A. planirostris, Carollia perspicillata e Glossophaga soricina-marcados em novembro foram recapturados em janeiro, indicando que estas espécies podem ser residentes. A dolina e a vegetação de entorno parecem representar importantes fontes de abrigo e alimento para a manutenção da fauna de morcegos.

Palavras-chave: abrigo diurno, Cerrado, diversidade, dolina, Nyctinomops laticaudatus. 


\section{Introduction}

Dolines (sinkholes) are soil depressions which occur in karstic reliefs. In the Aquidauana formation there were at least 25 dolines (Sallun Filho \& Karmann 2007). The doline Buraco das Araras is located in a geomorphologic transition area between arenite and subjacent dolomite, with the depth of arenite decreasing from east to west (Sallun Filho \& Karmann 2007). This doline is a very popular touristic destination and one of the foremost locations for observing birds and mammals in the Serra da Bodoquena region, Mato Grosso do Sul, Brazil. It has been used as a tourism enterprise since 1998, and received status of private reserve of natural patrimony in April 2007. The avian fauna of Buraco das Araras doline was reported by Pivatto et al. (2006) and the occurrence of the jellyfish Craspedacusta sowerbii in another doline of the region - Lagoa Misteriosa - was reported by Silva \& Roche (2007). However, to the best of our knowledge, there are no studies on the bat fauna inhabiting such peculiar environment. Some studies on the diversity of mammals, birds, amphibians, and reptiles in the Serra da Bodoquena and surrounding areas were carried out recently (Pivatto et al. 2006, Cáceres et al. 2007, Uetanabaro et al. 2007, Camargo et al. 2009). According to them, there are 16 recorded bat species in the Serra da Bodoquena region. Here we describe the bat species found in the Buraco das Araras natural reserve, and the using of the doline as dayroost by the bat Nyctinomops laticaudatus (E. Geoffroy 1805).

\section{Material and Methods}

The Private Reserve of Natural Patrimony Buraco das Araras ( $21^{\circ} 29^{\prime} 30^{\prime \prime} \mathrm{S}$ and $56^{\circ} 24^{\prime} 10^{\prime \prime} \mathrm{W}$ ) is located in Jardim, Mato Grosso do Sul, Brazil (Figure 1). The reserve area (29 ha) comprises the doline bordered by remnants of cerrado strict sense (IBGE 1992). Surrounding the reserve there are cattle ranches with wide pastures, in areas previously covered by cerrado strict sense and cerradão (Campelo-Júnior et al. 1997). The doline has an approximated elliptical shape $(70 \times 125 \mathrm{~m} ; 60 \mathrm{~m}$ deep $)$ with escarped cliffs and a permanent lake at the bottom of the depression. Vegetation inside the doline and in its neighboring is mainly composed of 3-8 m height shrubs and trees. Climate is Aw of Köppen, with average annual temperatures ranging from 22 to $25{ }^{\circ} \mathrm{C}$, and annual precipitation between 150 and $250 \mathrm{~mm}$ (Campelo-Júnior et al. 1997).

Bat captures were carried out in ten nights from November 8 to 11 of 2007 during waning and new moon, and from January 8 to 13 of 2008 during new moon, using five to eight mist nets of variable sizes $(9 \times 2.6 \mathrm{~m}, 12 \times 2.6 \mathrm{~m}$ and $18 \times 2.6 \mathrm{~m})$. Each night mist nets were opened at dusk (06:30 PM) and closed between 12:00 and 03:00 AM. In both expeditions the nets were set up on accessible trails surrounding the doline and in the adjacent forest. Each night in January we set one net intended for capturing $N$. laticaudatus individuals. This net was set across the observed route of these bats when leaving their roost in the doline, from dusk (06:30 PM) up to 07:30 PM. The total effort of capture (cf. Straube \& Bianconi 2002) was 9485 h.m², divided in 6037 h.m ${ }^{2}$ in November and 3448 h.m² in January. Rates of capture (number of captured bats divided by the sampling effort) were calculated to estimate the abundance of species.

Species identifications follow Vizotto \& Taddei (1973) modificated by W. Uieda (pers. comm.), Taddei (1983, 1996), Taddei et al. (1983), Simmons (1996), Anderson (1997), and Gregorin \& Taddei (2002). Species nomenclature follows Gardner (2007). To help identifications, bats' forearm length and mass were respectively measured with a caliper $( \pm 1 \mathrm{~mm})$ and a portable dynamometer $( \pm 1 \mathrm{~g})$. We also registered sex and reproductive stage (cf. Anthony 1988, Racey 1988), marked with aluminum numbered bands (approximately $0.23 \mathrm{~g}$ ) and released all captured bats, except 19 individuals collected as vouchers
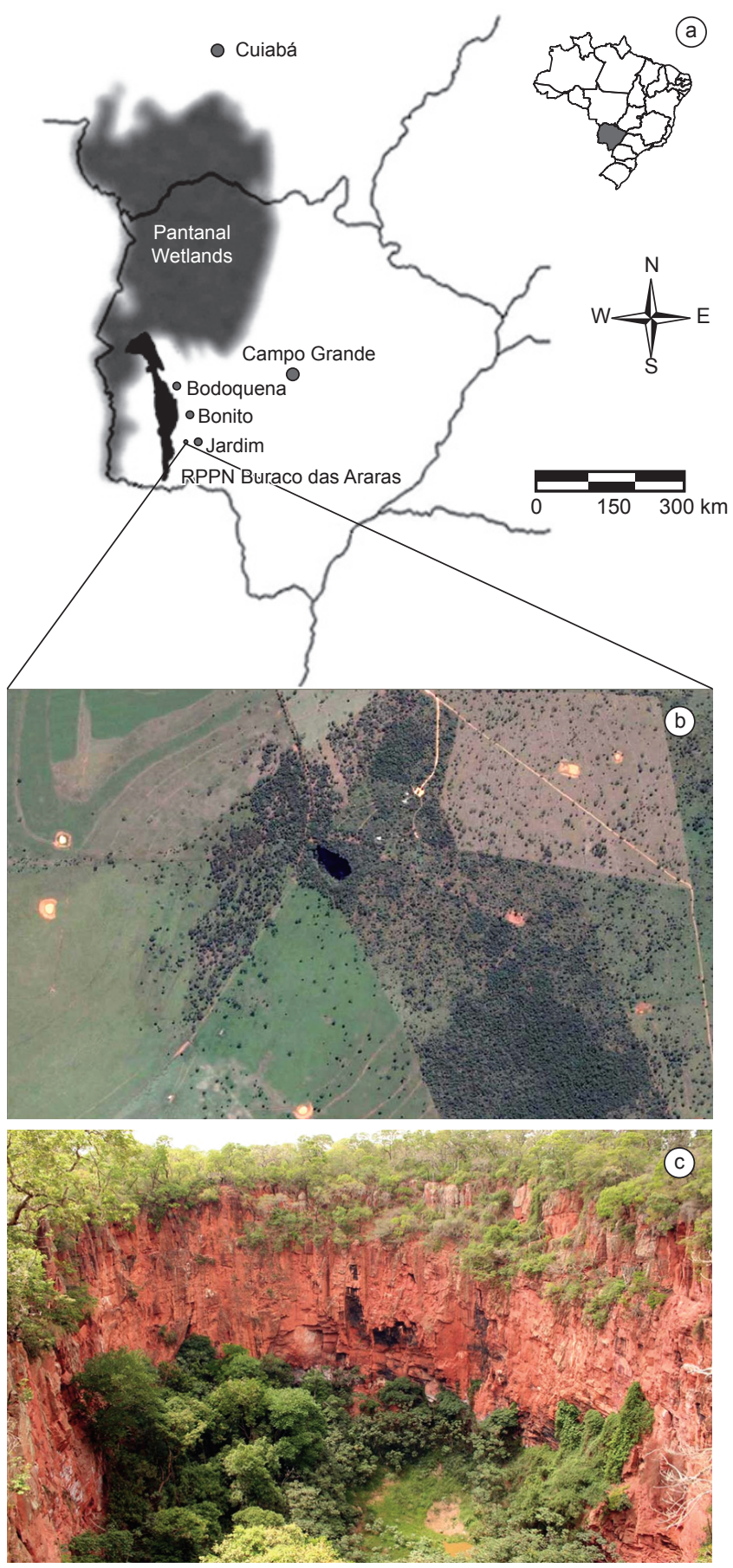

Figure 1. a) Location of the Buraco das Araras doline in Mato Grosso do Sul, Brazil, with the Serra da Bodoquena mountain indicated in black; b) the Buraco das Araras reserve surrounded by pastures; and c) note the vegetation and a small lake inside (photo: N. L. Cunha).

Figura 1. a) Localização da dolina Buraco das Araras no Mato Grosso do Sul, Brasil, com as montanhas da Serra da Bodoquena indicadas em preto; b) a reserva Buraco das Araras rodeada por pastos, c) notar a vegetação e o pequeno lago dentro (foto: N. L. Cunha).

and deposited in the zoological collection of the Universidade Federal de Mato Grosso do Sul (ZUFMS-M; Artibeus lituratus (Olfers 1818) - 316; A. planirostris (Spix 1823) - 315, 323, 324, 325, 326, 327, 328; Carollia perspicillata (Linnaeus 1758) - 313; Desmodus rotundus (E. Geoffroy 1810) - 314; Glossophaga soricina (Pallas 1766) - 311,314; 
Table 1. Number of captured male and female individuals of 10 species of bats, reproductive stage and trophic guild in the Buraco das Araras reserve, Jardim, Mato Grosso do Sul. Y: young, AT: abdominal testicle, ET: evident testicle; A: adult, P: pregnant, L: lactant, PL: pregnant and lactant.

Tabela 1. Número de indivíduos machos e fêmeas, estádio reprodutivo e guilda trófica de 10 espécies de morcegos capturados na reserva Buraco das Araras, Jardim, Mato Grosso do Sul. Y: jovens, AT: testículo abdominal, ET: testículo evidente; A: adulto, P: grávida, L: lactantes, PL: grávidas e lactantes.

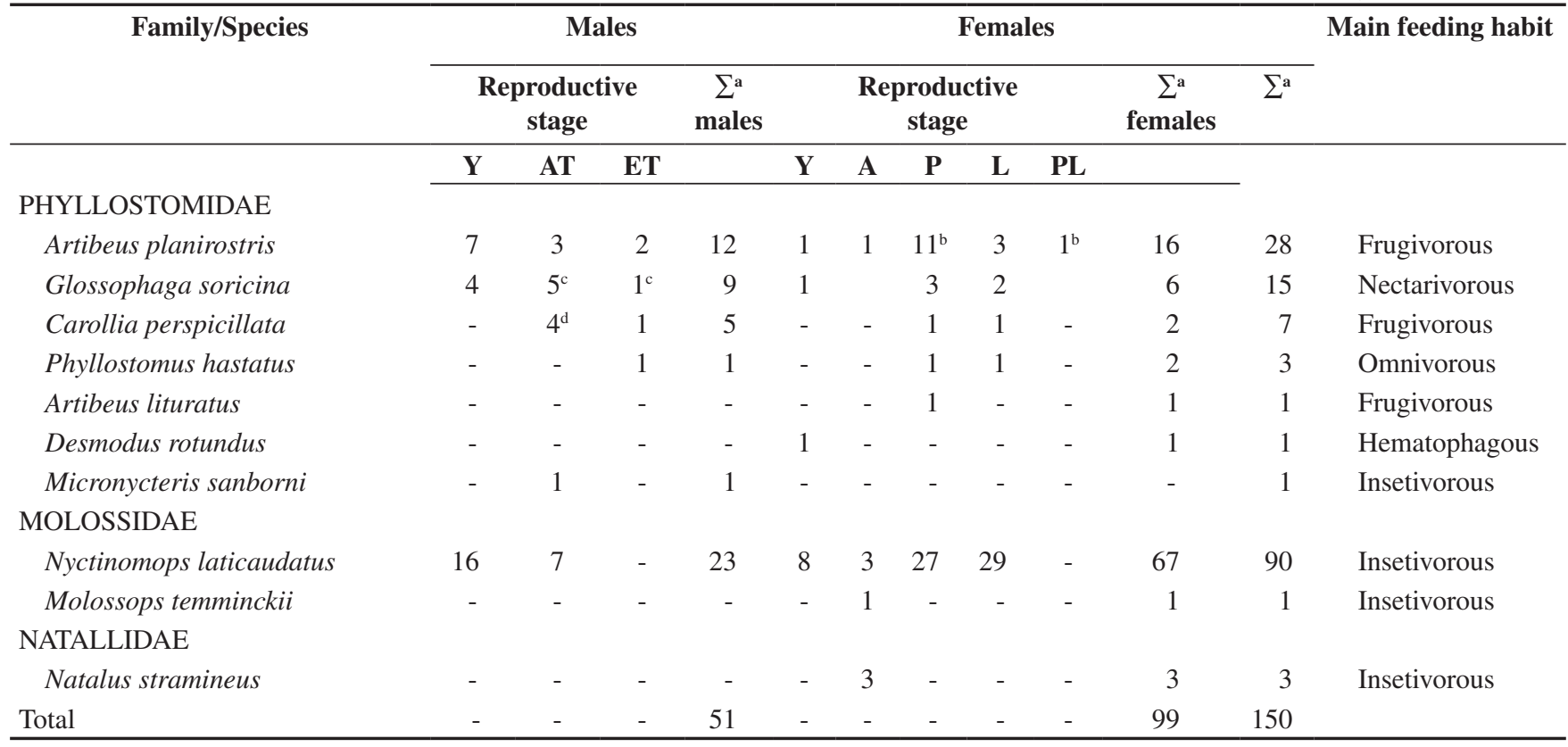

${ }^{a}$ Recaptured individuals were not summed.

${ }^{\mathrm{b}}$ One female P in November 2007 was recaptured as PL in January 2008.

c One male AT in November 2007 was recaptured as ET in January 2008.

${ }^{\mathrm{d}}$ One male AT in November 2007 was recaptured as AT in January 2008.
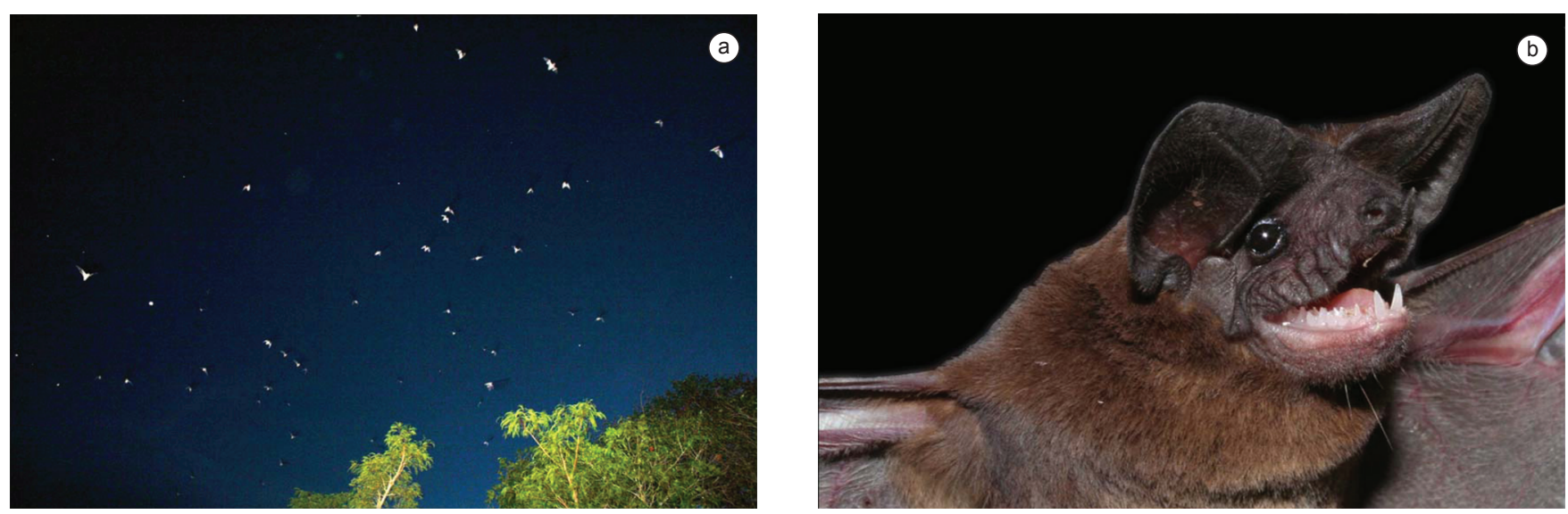

Figure 2. a) Flock of Nyctinomops laticaudatus (Molossidae) bats leaving their dayroost in the doline and b) individual of this species captured in the Buraco das Araras reserve, Jardim, Mato Grosso do Sul (photos: N. L. Cunha).

Figura 2. a) Revoada de morcegos Nyctinomops laticaudatus (Molossidae) deixando o abrigo diurno na dolina e b) indivíduos dessa espécie capturados na reserva Buraco das Araras, Jardim, Mato Grosso do Sul (fotos: N. L. Cunha).

Micronycteris sanborni Simmons 2006 - 161; Molossops temminckii (Burmeister 1854) - 291; Natalus stramineus Gray 1838 - 144; Nyctinomops laticaudatus - 290, 310; Phyllostomus hastatus (Pallas 1767) - 300, 301).

Shannon's diversity and Simpson's dominance indexes for the assemblage of bats of Buraco das Araras, as well as rarefaction curves were generated with PAST (Hammer et al. 2001); analyses were done with and without individuals captured in the net across $N$. laticaudatus route.

\section{Results}

We captured 150 bats belonging to 10 species, nine genus and three families (Table 1). Twenty-nine individuals were recorded in November (nine were collected and 20 released), and 124 in January when $90 \mathrm{~N}$. laticaudatus bats were caught leaving the dayroost. Among the 20 released bats in November, three individuals were recaptured on January, corresponding to $15 \%$ of recapture rate. Phyllostomidae was the richest family, comprising seven species 
( $\mathrm{n}=56$ individuals); Natalidae presented one ( $\mathrm{n}=3$ individuals $)$, and Molossidae two species ( $\mathrm{n}=91$ individuals) (Table 1).

The most abundant phyllostomid species were Artibeus planirostris, Carollia perspicillata and Glossophaga soricina, registered in November and in January. Phyllostomus hastatus was registered in both expedition dates; in January one male was captured in front of flowers of Bauhinia rufa (Bong.) Steudel (Fabaceae) and showed pollen on its anterior body's parts. Artibeus lituratus, Desmodus rotundus and Micronycteris sanborni presented only one captured exemplar, corresponding to approximately $2 \%$ of the captured individuals.

Nyctinomops laticaudatus was the most abundant species, but registered only in January. Activity of $N$. laticaudatus started at dusk ( 06:30 PM), when hundreds of individuals flight in circles inside the doline. After complete darkness, individuals of $N$. laticaudatus left the doline in dense flocks (Figure 2), continuously during approximately 40 minutes. When leaving the doline, all bats flight northeastwards, passing over a gap of trees in the doline border. The bats returned to the roost throughout the night. Most captured individuals of $N$. laticaudatus were pregnant or lactant females (Table 1). Other molossid recorded was Molossops temminckii, with one male captured in front of $B$. rufa flowers with pollen on its rostrum and upper lip (Figure 3).

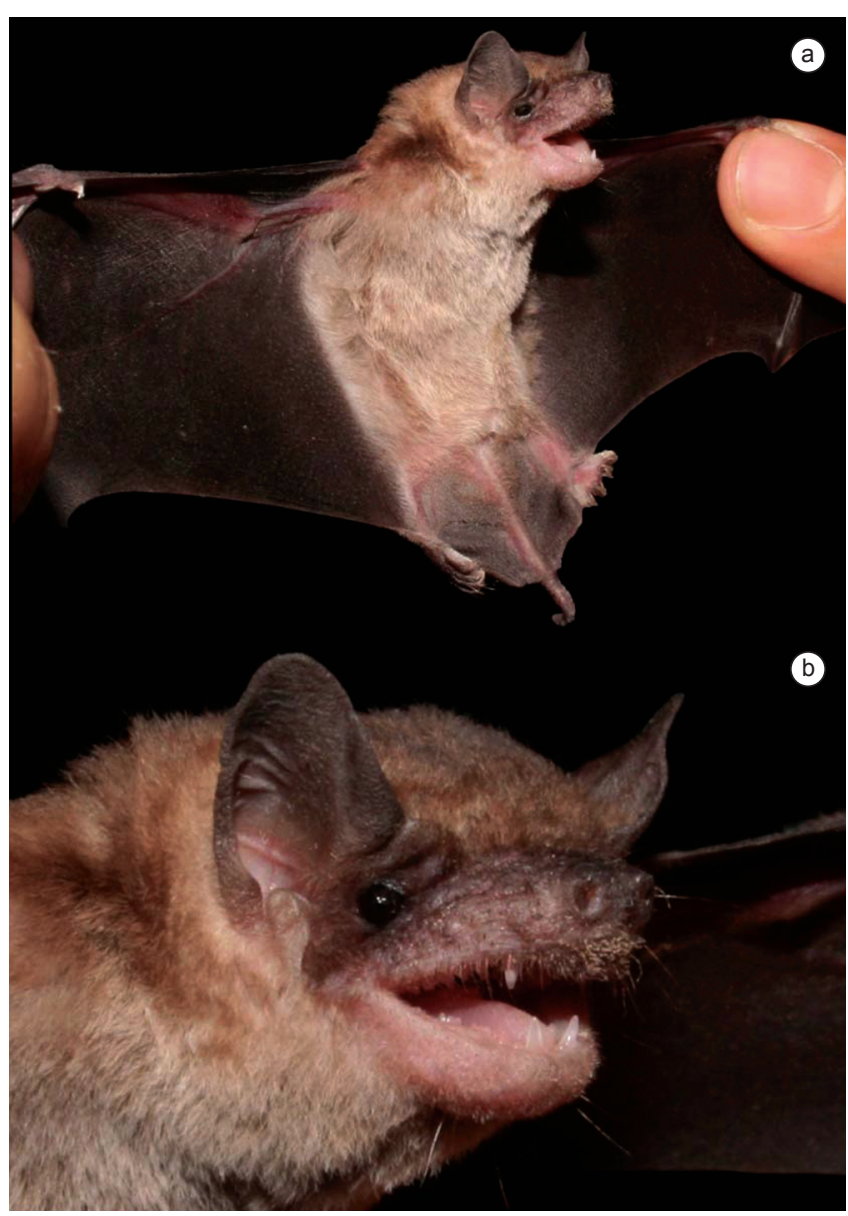

Figure 3. a) Individual of Molossops temminckii (Molossidae) captured in the Buraco das Araras reserve in front of Bauhinia rufa (Fabaceae) flowers; b) note the presence of pollen on the bat's superior lip (photos: N. L. Cunha).

Figura 3. a) Indivíduo de Molossops temminckii (Molossidae) capturado na reserva Buraco das Araras em frente a flores de Bauhinia rufa (Fabaceae); b) notar a presença de pólen no lábio superior do morcego (fotos: N. L. Cunha).
The bat capture rate was 0.016 individuals per hour per squared meter of mist-nets $\left(\mathrm{N} \cdot \mathrm{h}^{-1} \cdot \mathrm{m}^{-2}\right)$. Excluding those nets directed for capturing $N$. laticaudatus, A. planirostris was the dominant species (Figure 4). Shannon's diversity and Simpson's dominance indexes including all species sampled in the Buraco das Araras were respectively 1.303 and 0.396 ; excluding $N$. laticaudatus, these indexes were respectively 1.52 and 0.298 . Rarefaction curve excluding captures of $N$. laticaudatus demonstrates that richness of bat species tends to increase fast with additional inventories (Figure 5).

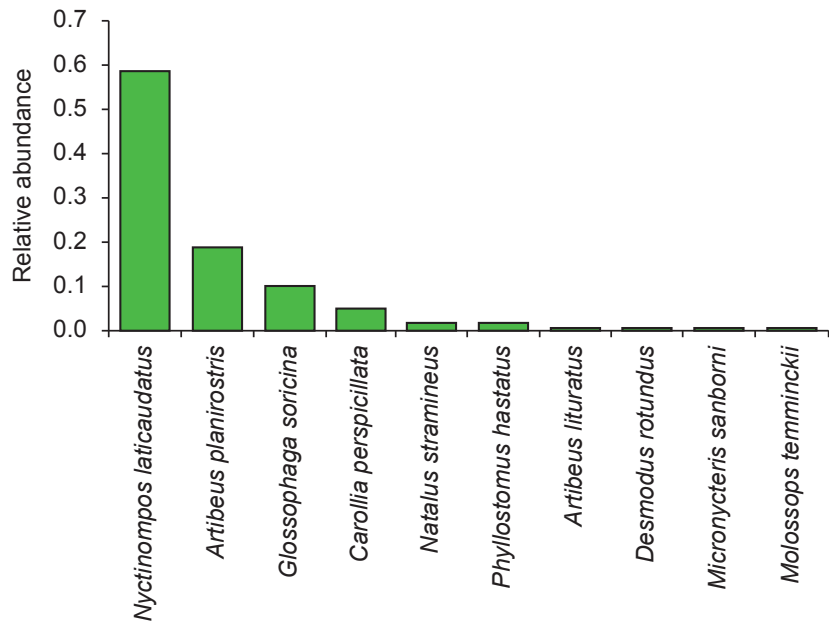

Bat species

Figure 4. Rank-abundance distribution of the recorded species of bats in the Buraco das Araras reserve, Jardim, Mato Grosso do Sul.

Figura 4. Distribuição de abundância das espécies de morcegos registradas na reserva Buraco das Araras, Jardim, Mato Grosso do Sul.

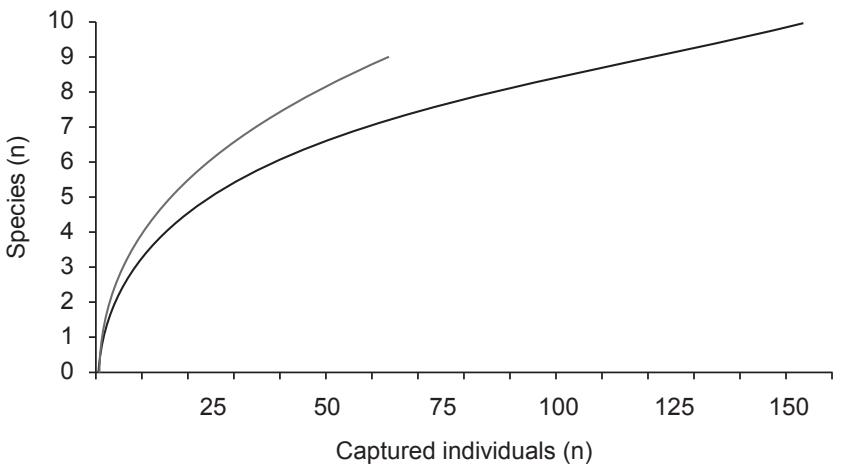

Figure 5. Rarefaction curves for bats sampled in the Buraco das Araras reserve, Jardim, Mato Grosso do Sul. Black line corresponds to the estimative including Nyctinomops laticaudatus (Molossidae) bats and the gray line to the estimative without this species.

Figura 5. Curvas de rarefação de morcegos amostrados na reserve Buraco das Araras, Jardim, Mato Grosso do Sul. Linha preta corresponde à estimativa incluindo os morcegos Nyctinomops laticaudatus (Molossidae) e a linha cinza às estimativas sem essa espécie. 


\section{Discussion}

Of the ten registered species, six were previously reported for the Serra da Bodoquena and surrounding areas (Camargo et al. 2009, Cáceres et al. 2007), and four are new records for this region P. hastatus, M. sanborni, M. temminckii and N. laticaudatus. However, except for $M$. sanborni, these species were already reported to occur in Mato Grosso do Sul (Cáceres et al., 2008), and so our findings could be partially expected. Considering data available in literature along with data from the present study, the known bat fauna for the region includes 20 species, corresponding to $18 \%$ of the species known to occur on the Cerrado ( $n=107$; Zortéa $\&$ Tomaz 2006) and $31 \%$ of the species reported on the Pantanal ( $n=63$; Marinho-Filho \& Sazima 1998, Camargo \& Fischer 2005, Longo et al. 2007).

Seven out of ten captured species were Phyllostomidae, a result partially expected due to the using of mist nets (Barnett et al. 2006). All phyllostomids recorded here are common in Cerrado and Pantanal regions, except Micronycteris sanborni. In Mato Grosso do Sul, only two other species of this genus have already been registered, M. megalotis (Gray 1842) and M. minuta (Gervais 1856) (PulchérioLeite et al. 1998, Bordignon \& França 2009). The only individual of $M$. sanborni that we recorded in the Buraco das Araras was deposited in the ZUFMS-M collection and previously misidentified: Cáceres et al. (2008) erroneously cited this specimen as M. schimidtorum Sanborn 1935. Morphometric data on this specimen and discussion about taxonomy and species distribution are provided elsewhere (C.F. Santos et al., submitted manuscript).

Phyllostomus hastatus is another new species registered for the Serra da Bodoquena; it is omnivorous, feeding on small vertebrates, insects, pollen, nectar, and fruits (Gardner 2007, Santos et al. 2003). Our capture of a P. hastatus male was in front of a flowering B. rufa, a bat-pollinated species, when an individual of $G$. soricina already was in the net. Thus $P$. hastatus might have been attracted to floral resources or to the potential prey represented by the netted G. soricina. Bat distress calls in stressing situations, as when netted, are known to attract predators (Altringham \& Fenton 2003). Four events of $P$. hastatus being attracted to mist-netted bats were already reported (Oprea et al. 2006).

The dominance of A planirostris over other phyllostomids in the Buraco das Araras corroborates previous studies conducted in the Pantanal and in neighboring regions of Cerrado (Camargo 2003, Fischer et al. 2004, Cáceres et al. 2007, Camargo et al. 2009, Teixeira et al. 2009). The three most captured phyllostomid species in the Buraco das Araras reserve - A. planirostris, G. soricina, and C. perspicillata - are among the commonest ones reported to the Cerrado domain (e.g. Bordignon 2006, Zortéa \& Alho 2008, Camargo et al. 2009). However, other typical phyllostomids of Cerrado, like Anoura spp., Platyrrhinus lineatus (E. Geoffroy 1810), and Sturnira lilium (E. Geoffroy 1810), were not recorded in the Buraco das Araras. Glossophaga soricina was the second most frequent phyllostomid at the study site, but Cáceres et al. (2007) and Camargo et al. (2009) registered low abundance $(n=3)$ and absence of this species in different regions of the Serra da Bodoquena, respectively. Since G. soricina commonly roosts in large caves in karstic regions (Trajano 1985), its relatively high abundance in the Buraco das Araras might be related to the presence of a large dayroost place, offered by the doline. Nonetheless, the Buraco das Araras doline did not resemble caves regarding to the associated bat fauna. Contrasting to our data, assemblages of cave bats in karstic Brazilian regions include mainly D. rotundus and $C$. perspicillata, and other frequent bats are Anoura caudifer (E. Geoffroy 1818), A. geoffroyi Gray 1838, and Lonchophylla dekeyseri Taddei, Vizotto \& Sazima 1983 (Trajano 1985, 2000, Baumgarten \& Vieira 1994, Fischer et al. 1997, Bredt et al. 1999).
The massive occurrence of $N$. laticaudatus in the Buraco das Araras doline is not constant over the year, since it was not registered in November, but was later observed during January. In addition, the local inhabitants reported that dense flocks of bats (probably $N$. laticaudatus) occur annually from late December to early February only, indicating that $N$. laticaudatus uses the doline as an intermittent and short-term dayroost during the peak of the wet season. On the other hand, resident colonies, with constant number of individuals throughout the year, have been reported for $N$. laticaudatus elsewhere (Avila-Flores et al. 2002). Migratory behavior and large colonies for the molossid Tadarida brasiliensis (I. Geoffroy 1824) was indeed described in North America (Spenrath \& La Val 1974, Gardner 2007). Further studies may find out whether migration occurs among Brazilian molossids. The high proportion of pregnant or lactant females $(62 \% ; 56 / 90)$, the low proportion of adult males $(8 \% ; 7 / 90)$ and the apparently non-reproductive condition of males (100\% presenting abdominal testicles) indicate that the doline Buraco das Araras might be a maternity and nursery roost for $N$. laticaudatus. This proportion highly deviated towards reproductive female points out that individuals of $N$. laticaudatus may be grouping themselves during the neonatal period and dispersing after the end of lactation, such as described to T. brasiliensis and Molossus rufus E. Geoffroy 1805 (Molossidae) (Spenrath \& La Val 1974, Gardner 2007, Esbérard 2002).

Molossops temminckii was another insectivorous bat recorded in the Buraco das Araras whose captures are uncommon, probably because it generally flies $4 \mathrm{~m}$ or more above ground and it presents high capacity to detect mist nets (Kalko \& Schnitzler 1998). Individuals of $M$. temminckii were already found in the region of Miranda River, Pantanal, and in the northeast Cerrado in Mato Grosso do Sul (Pulchério-Leite et al. 1998, Bordignon 2006). On Bolivian savanna, this species was mainly registered in vegetation borders (Aguirre et al. 2007). The presence of pollen on M. temminckii rostrum is an unexpected finding, as we did not find similar records among molossids. Predation upon flower-visiting insects carrying pollen might explain the presence of pollen on the bat. An alternative hypothesis, conversely, is that pollen was actively consumed by the $M$. temminckii individual, as already suspected for the insectivorous bat Noctilio albiventris Desmarest 1818 (Noctilionidae) in the Pantanal (Gonçalves et al. 2007).

The proportion of bats recaptured in January (15\%) was almost twice higher than that reported in the Atlantic Forest (8,5\%) (Bianconi et al. 2006). Because bats tend to roost near food sources in order to reduce costs of foraging (Erkert 1982), the recaptures indicate that some bat species inhabit the Buraco das Araras reserve. Therefore our results suggest that Buraco das Araras reserve is a relevant site for bat feeding and roosting in the Serra da Bodoquena region.

\section{Acknowledgements}

We are grateful to Maria Antonietta Castro Pivatto for inviting us to study bats in the doline; to Modesto Sampaio and his family for kindly sharing their knowledge on doline's species and history, and for logistic support in the field; to Marcelo Nogueira for identification of M. sanborni; to anonymous referees for helpful comments on early versions; and to Conservation International for financial support. This study is part of the Buraco das Araras natural reserve management plan; bat captures were carried out under license of IBAMA (10615-2007).

\section{References}

AGUIRRE, L.F., BARBOZA, K. \& KALKO, E.K.V. 2007. Use of acoustic methods for bat inventory and habitat use studies in Bolívia. In Annals of 
the XIV International Bat Research Conference, 37th NASBR, Mérida, YUC, Mexico. Program and Abstracts.

ALTRINGHAM, J.D. \& FENTON, M.B. 2003. Sensory ecology and communication in the Chiroptera. In Bat ecology (T.H. Kunz \& M.B. Fenton, eds). The University of Chicago Press, Chicago, 779 p.

ANDERSON, S. 1997. Mammals of Bolivia, taxonomy and distribution. Bulletin of the American Museum of Natural History (231):1-652.

ANTHONY, E.C.P. 1988. Age determination in bats. In Ecological and behavioral methods for the study of bats. (T.H. Kunz, ed.) Smithsonian Institution Press, Washington, p. 47-58.

AVILA-FLORES, R., FLORES-MARTÍNEZ, J.J. \& ORTEGA, J. 2002. Nyctinomops laticaudatus. Mammalian Species (697):1-6.

BARNETT A.A., SAMPAIO E.M., KALKO E.K.V., SHAPLEY R.L., FISCHER E., CAMARGO, G. \& HERRERA, B.R. 2006. Bats of Jaú National Park, central Amazônia, Brazil. Acta Chiropterologica (8):103-128.

BAUMGARTEN, J.E. \& VIEIRA, E.M. 1994. Reproductive seasonality and development of Anoura geoffroyi (Chiroptera: Phyllostomidae) in central Brazil. Mammalia (58):415-422.

BIANCONI, G.V., MIKICH, S.B.\& PEDRO, W.A. 2006. Movements of bats (Mammalia, Chiroptera) in Atlantic Forest remnants in southern Brazil. Revista Brasileira de Zoologia (23):1199-1206.

BORDIGNON, M.O. 2006. Diversidade de morcegos (Mammalia, Chiroptera) do Complexo Aporé-Sucuriú, Mato Grosso do Sul, Brasil. Revista Brasileira de Zoologia (24):1002-1009.

BORDIGNON, M.O. \& FRANÇA, A.O. 2009. Riqueza, diversidade e variação altitudinal em uma comunidade de morcegos filostomídeos (Mammalia: Chiroptera) no Centro-Oeste do Brasil. Chiroptera Neotropical (15):425-433.

BREDT, A., UIEDA, W. \& MAGALHÃES, E.D. 1999. Morcegos cavernícolas da região do Distrito Federal, centro-oeste do Brasil (Mammalia, Chiroptera). Revista Brasileira de Zoologia (16):731-770.

CÁCERES, N.C., BORNCHEIN, M.R., LOPES, W.H. \& PERCEQUILLO, A.R. 2007. Mammals of the Bodoquena Mountains, southwestern Brazil: an ecological and conservation analysis. Revista Brasileira de Zoologia (24):426-435

CÁCERES, N.C., CARMIGNOTTO, A.P., FISCHER, E. \& SANTOS, C.F. 2008. Mammals from Mato Grosso do Sul, Brazil. Check List. (4):321-335.

CAMARGO, G. 2003. Riqueza e diversidade de morcegos no Pantanal do Miranda-Abobral, Mato Grosso do Sul. Dissertação de Mestrado, Universidade Federal de Mato Grosso do Sul, Mato Grosso do Sul.

CAMARGO, G. \& FISCHER, E. 2005. Primeiro registro do morcego Mimon crenulatum (Phyllostomidae) no Pantanal, sudoeste do Brasil. Biota Neotropica 5(1): http://www.biotaneotropica.org.br/v5n1/pt/ abstract?shortcommunication+ BN00705012005 (último acesso em $15 / 10 / 2009)$.

CAMARGO, G., FISCHER, E., GONÇALVES, F., FERNANDES, G. \& FERREIRA, S. 2009. Morcegos do Parque Nacional da Serra da Bodoquena, Mato Grosso do Sul, Brasil. Chiroptera Neotropical. (15):417-424.

CAMPELO Jr., J.H., SANDANIELO, A., CANEPPELE, C.R. \& SORIANO, B.M.A. 1997. Climatologia. In Plano de Conservação da Bacia do Alto Paraguai - PCBAP Meio Físico. Ministério do Meio Ambiente, Brasília, p. 309-349. (Programa Nacional do Meio Ambiente, v. 2, tomo 1).

ERKERT, H.G. 1982. Ecological aspects of bat activity Rhythms. In Ecology of bats (T.H. Kunz Ed.) Plennun Press, New York, p. 201-236.

ESBÉRARD, C.E.L. 2002. Composição da colônia e reprodução de Molossus rufus em refúgio no sudeste do Brasil (Mammalia, Molossidae). Revista Brasileira de Zoologia (19):1153-1160.

FISCHER, E., ARAÚJO, A.C., CAMARGO, G. \& LONGO, J.M. 2004. Bat assemblages in the Rio Negro and Nhecolândia regions. In The pantanal conservation research initiative (M. Chandler \& P. Johansson, eds.). Earthwatch Institute, Maynard, p. 63-72.
FISCHER, E., FISCHER, W.A., BORGES, S., PINHEIRO, M.R. \& VICENTINI, A. 1997. Predation of Carollia perspicillata by Phyllostomus cf. elongatus in Central Amazonia. Chiroptera Neotropical (3):67-68.

GARDNER, A.L. 2007. Mammals of South America. University of Chicago Press, Chicago, p. 1-690.

GONÇALVES, F., MUNIN, R., COSTA, P. \& FISCHER, E. 2007. Feeding habits of Noctilio albiventris (Noctilionidae) bats in the Pantanal, Brazil. Acta Chiropterologica (9):535-546.

GREGORIN, R. \& TADDEI, V.A. 2002. Chave artificial para a identificação de molossídeos brasileiros (Mammalia, Chiroptera). Mastozoologia Neotropical (9):13-32.

HAMMER, Ø., HARPER, D.A.T. \& RYAN, P.D. 2001. PAST: Paleontological Statistics Software Package for Education and Data Analysis. Palaeontologia Electronica. (4): http://palaeo-electronica.org/2001_1/ past/issue1_01.htm (último acesso em 10/09/2009).

Instituto Brasileiro de Geografia e Estatística - IBGE. 1992. Manual técnico da vegetação brasileira. IBGE, Rio de Janeiro, p. 1-92.

KALKO, E.K.V. \& SCHNITZLER, H.U. 1998. How echolocating bats approach and acquire food. In Bat biology and conservation. (T.H. Kunz \& P.A. Racey, eds.).Smithsonian Institution Press, Washington, p. 197-204.

LONGO, J.M., FISCHER E., CAMARGO, G. \& SANTOS, C.F. 2007. Ocorrência de Vampyressa pusilla (Chiroptera, Phyllostomidae) no Pantanal sul. Biota Neotropica. n.7(3): http://www.biotaneotropica. org.br/v7n3/pt/abstract?shortcommunication+bn024070320 07 (último acesso em 08/09/2009).

MARINHO-FILHO, J.S. \& SAZIMA, I. 1998. Brazilian bats and conservation. In Bat biology and conservation (T.H. Kunz \& P. Racey, eds.). Smithsonian Institution Press, Washington, p. 282-294

OPREA, M., VIEIRA, T.B., PIMENTA, V.T., MENDES, P., BRITO, D., DITCHFIELD, A.D., KNEGT, L.V.D. \& ESBÉRARD, C.E.L. 2006. Bat predation by Phyllostomus hastatus. Chiroptera Neotropical (12):262-267.

PIVATTO, M.A.C., MANÇO, D.G., STRAUBE, F.C., URBEN-FILHO, A., MILANO, M. 2006. Aves do Planalto da Bodoquena, Estado do Mato Grosso do Sul (Brasil). Atualidades ornitológicas (129):28-29.

PULCHÉRIO-LEITE, A., TADDEI, V.A. \& MENEGHELLI, M. 1998. Morcegos(Chiroptera: Mammalia) dos Pantanais de Aquidauana e da Nhecolândia, Mato Grosso do Sul: I Diversidade de espécies. Revista Ensaios e Ciência. (2):149-163.

RACEY, P.A. 1988. Reproductive assessment in bats. In Ecological and behavioral methods for the study of bats (T.H. Kunz, ed). Smithsonian Institution, Washington, p. 31-46.

SALLUN-FILHO, W. \& KARMANN, I. 2007. Dolinas em arenitos da Bacia do Paraná: evidências de carste subjacente em Jardim (MS) e Ponta Grossa (PR). Revista Brasileira de Geociências (37):551-564.

SANTOS, M., AGUIRRE, L.F., VÁZQUEZ, L.B., ORTEGA, J. 2003 Phyllostomus hastatus. Mammalian Species (722):1-6.

SILVA, W.M. \& ROCHE, K.F. Ocorrência da água-viva de água doce Craspedacusta sowerbii (Lankester,1880) (Hydrozoa, Limnomedusae) em um lago calcário no Estado do Mato Grosso do Sul, Brasil. Biota Neotropica 7(1):http://www.biotaneotropica.org.br/v7n1/pt/ abstract?short-communication+bn02107012007 (último acesso em 09/09/2009).

SIMMONS, N.B. 1996. A new species of Micronycteris (Chiroptera: Phyllostomidae) from Northeastern Brazil, with comments on phylogenetic relationships. American Museum Novitates (3158):1-34.

SPENRATH, C.A. \& LA-VAL, R. 1974. An ecological study of a resident population of Tadarida brasiliensis in eastern Texas. Occasional Papers, The Museum, Texas Tech University (21):1-14.

STRAUBE, F.C. \& BIANCONI, G.V. 2002. Sobre a grandeza e a unidade utilizada para estimar esforço de captura com utilização de redes-deneblina. Chiroptera Neotropical (8):150-152. 
TADDEI, V.A. 1983. Morcegos: algumas considerações sistemáticas e biológicas. Boletim Técnico, Coordenadoria de Assistência Técnica Integral (72):1-31.

TADDEI, V.A. 1996. Sistemática de Quirópteros. Boletim do Instituto Pasteur. (1):3-15.

TADDEI, V.A., VIZOTTO, L.D. \& SAZIMA, I. 1983. Uma nova espécie de Lonchophylla do Brasil e chave para identificação das espécies do gênero (Chiroptera, Phyllostomidae). Ciência e Cultura (35):625-629.

TEIXEIRA, R.C., CORREA, C.E. \& FISCHER, E. 2009. Frugivory by Artibeus jamaicensis (Phyllostomidae) bats in the Pantanal, Brazil. Studies on Neotropical Fauna and Environment (44):7-15.

TRAJANO, E. 1985. Ecologia de populações de morcegos cavernícolas em uma região cárstica do sudeste do Brasil. Revista Brasileira de Zoologia (2):255-320.

TRAJANO, E. 2000. Cave faunas in the Atlantic tropical rainforest: composition, ecology, and conservation. Biotropica. (32):882-893.
UETANABARO, M., SOUZA, F.L, LANDGREF-FILHO, P., BEDA, A.F. \& BRANDÃO, R.A. 2007. Anfíbios e répteis do Parque Nacional da Serra da Bodoquena, Mato Grosso do Sul, Brasil. Biota Neotropica. (7): http://www.biotaneotropica.org.br/v7n3/pt/fullpaper?bn01207032007+pt (último acesso em 09/09/2009).

VIZOTTO, L.D. \& TADDEI, V.A. 1973. Chave para determinação de quirópteros brasileiros. Revista da Faculdade de Ciências e Letras de São José do Rio Preto - Boletim de Ciências (1):1-72.

ZORTÉA, M. \& ALHO, C.J.R. 2008. Bat diversity of a Cerrado habitat in central Brazil. Biodiversity and Conservation (17):791-805.

ZORTÉA, M. \& TOMAZ, L.A.G. 2006. Dois novos registros de morcegos (Mammalia, Chiroptera) para o Cerrado do Brasil Central. Chiroptera Neotropical (12):280-285. 